\title{
EFFECT OF STRAW SUBSTITUTING PARTIAL MINERAL N FERTILIZER ON N DISTRIBUTION OF MAIZE PLANTS AND SOIL IN NORTHEAST CHINA
}

\author{
LIU, J. H. ${ }^{1,2}-$ GENG, Y. H. ${ }^{1}-$ LI, J. ${ }^{1}-$ CAO, G. J. ${ }^{1 *}-$ ZHANG, Z. Q. ${ }^{1}$ \\ ${ }^{1}$ College of Resources and Environment, Jilin Agricultural University, Changchun, Jilin \\ 130118, P. R. China \\ ${ }^{2}$ National experimental teaching demonstration center for agricultural resources and \\ environment, Jilin Agricultural University, Changchun, Jilin 130118, P. R. China \\ (phone: +86-0431-8453-2955) \\ *Corresponding author \\ e-mail:cgj72@126.com
}

(Received $11^{\text {th }}$ Sep 2020; accepted $30^{\text {th }}$ Nov 2020)

\begin{abstract}
Reducing mineral $\mathrm{N}$ fertilizer application rate and improving $\mathrm{N}$ use efficiency is important for sustainable agriculture. Whether straw return could substitute partial mineral $\mathrm{N}$ fertilizer in the applying year is still not conclusive in the case of spring corn planting in Northeast China. This work was conducted to investigate the optimal substitution rate through a field experiment with no fertilization (CK), $100 \%$ mineral $\mathrm{N}$ (IF), $25 \% / 50 \% / 75 \% / 100 \%$ straw application combined with reduced mineral $\mathrm{N}$ fertilizer (S25/ S50/ S75/ S100) at a total of $240 \mathrm{~kg} \mathrm{~N} / \mathrm{hm}^{2}$ application rate in Jilin Province, Northeast China. The results showed that there was no significant difference in corn yield between straw application treatments and IF except for S100, which was $11.1 \%$ lower. Compared to IF, corn straw application did not affect $\mathrm{N}$ uptake amount and nitrogen harvest index ( $p>0.05$ ), while $\mathrm{S} 75$ obviously increased $\mathrm{N}$ use efficiency by $29.6 \%$. Straw application decreased $\mathrm{NO}_{3}{ }^{-}-\mathrm{N}$ content and resisted downward migration in the soil profile. In conclusion, integrated application of $75 \%$ corn straw with reduced mineral $\mathrm{N}$ fertilizer at a total of $240 \mathrm{~kg} \mathrm{~N} / \mathrm{hm}^{2}$ was a reasonable fertilization practice as it reduced $\mathrm{NO}_{3}^{-}-\mathrm{N}$ content and prevented leaching in soil profile as well as increased $\mathrm{N}$ use efficiency without negative effect on corn yield.
\end{abstract}

Keywords: yield, equal $\mathrm{N}$ application rate, $\mathrm{NH}_{4}{ }^{+}-\mathrm{N}, \mathrm{NO}_{3}{ }^{-}-\mathrm{N}$, nitrogen use efficiency

\section{Introduction}

Nitrogen, as one of the three essential nutrient elements for crop production, plays an important role in the growth of stems, leaves and grains as it is the main component of protein. In order to obtain high crop yield, enough nitrogen should be supplied to plants during their growth. Mineral nitrogen is extensively used for crop production worldwide and urea is the most commonly used in China (Zhu et al., 2002). While sufficient application of mineral nitrogen fertilizer increases crop yield and quality, its negative impacts on the environment have been documented, such as soil acidification and compaction (Guo et al., 2010; Cai et al., 2015), eutrophication of surface water (Zhang et al., 2011), contamination of groundwater (Hillin et al., 2003; De Paz et al., 2004), accelerating global warming by greenhouse gases emission (Galloway et al., 2003; Battye et al., 2017).

Spring corn is one of the dominant crops in Northeast China, where one third of corn grains in China is produced. The most common fertilization practice in this area is to use $100 \%$ mineral N fertilizer. During 1980 to 2010, the application rate of nitrogen for corn in this area has been steadily growing from $100 \mathrm{~kg} \mathrm{~N} / \mathrm{hm}^{2}$ to more than $300 \mathrm{~kg} \mathrm{~N} / \mathrm{hm}^{2}$ (Gao et al., 2010), while the nitrogen use efficiency dropped from $52.6 \%$ to $20 \%$ (Zhang 
et al., 2008; Cui et al., 2008; Zhi et al., 2020) and its adverse effect has been observed. However, what concurrently happening is less applying organic fertilizer such as animal manure and straw in farmland mainly due to the inconvenient application of such materials.

As planting area and grain yield of corn is growing steadily in Northeast China, corn straw is also rising in recent years. In 2015, the total corn straw yield in Northeast China was 159 million tons, accounting for 19.2\% of the national straw output (Li et al., 2017a). How to dispose such large amount of straw in a short-term is still a challenge to local farmer since the low temperature and humidity of soil makes decomposition process slow. In the past several decades, most of corn straw was burnt after harvest or before sowing, which resulted in the loss of organic matter reduced to soil as well as serious air pollution. In order to solve these problems and improve the fertility of black soil, conservation tillage which includes less or no tillage combined with straw application has been recommended. Numerous studies have proved that straw application could improve soil fertility, water holding capacity and carbon sequestration (Liu et al., 2014; Li et al., 2016).

Compared with mineral fertilizer, corn straw has lower $\mathrm{N}$ concentration and slower releasing rate, which greatly increases $\mathrm{N}$ use efficiency and reduces $\mathrm{N}$ loss via farmland runoff. Furthermore, the application of crop straw in farmland soil also alleviates the issue of wastes disposal in corn production. Thus, straw application combined with mineral fertilizer has been recommended by many scientists in recent years (Rasool et al., 2008; Lu et al., 2009; Demelash et al., 2014; Zhang et al., 2015).

As discussed above, corn straw application is beneficial for soil and crop growth. While one remarkable thing is that the results were obtained on the base of the constant amount of mineral $\mathrm{N}$ fertilizer combined with more corn straw (Wang et al., 2018a; Afreh et al., 2018). Few researches were carried out on equally total nitrogen application amount (organic $\mathrm{N}+$ mineral $\mathrm{N}$ ) on spring corn in Northeast China. So, there is little knowledge about whether corn straw application could substitute partial mineral $\mathrm{N}$ fertilizer. In addition, many long-term experiments have been taken to evaluate the effect of corn straw on soil properties and crop growth after several years of application (Wang et al., 2018b; $\mathrm{Xu}$ et al., 2019). However, its temporal influence was seldom estimated in the fertilization year, which might bring some undesirable negative impacts on yield and soil environment.

In this paper, integrated various ratio of corn straw to mineral $\mathrm{N}$ fertilizer at an equally total $\mathrm{N}$ application rate of $240 \mathrm{~kg} \mathrm{~N} / \mathrm{hm}^{2}$ was studied in the fertilization year to evaluate its effect on (1) corn yield, (2) nitrogen uptake characteristics of corn plants in different growth stage, (3) nitrate, ammonium distribution in the soil profile $(0-100 \mathrm{~cm})$. We assumed that an appropriate ratio of straw application could substitute partial mineral $\mathrm{N}$ fertilizer characterized by higher $\mathrm{N}$ use efficiency, less $\mathrm{NO}_{3}{ }^{-}-\mathrm{N}$ content and leaching in soil profile without negative effect on corn yield.

\section{Material and Methods}

\section{Field experimental site and design}

Field work was conducted at the experimental station of Jilin Agricultural University $\left(43^{\circ} 49^{\prime} 6.6^{\prime \prime} \mathrm{N}, 125^{\circ} 23^{\prime} 56.4^{\prime \prime} \mathrm{E}\right)$, which lies in Changchun City, Jilin province in Northeast China. It is a continental monsoon climate with an average annual rainfall of $582 \mathrm{~mm}$ (more than $60 \%$ of the rainfall occurs during June to August) and average annual temperature of $5.5^{\circ} \mathrm{C}$. The sunshine time is 2688 hours per year and the annual average 
effective accumulated temperature is $2900^{\circ} \mathrm{C}$. The frost free period is 132 days per year. The soil is classified as phaeozems according to FAO soil taxonomy, and maize has been planted at least 20 years without straw return. Analyses indicated $\mathrm{pH}$, organic matter, total $\mathrm{N}$, available $\mathrm{N}, \mathrm{P}$ and $\mathrm{K}$ of the top $0-20 \mathrm{~cm}$ soil was $6.89,27.4 \mathrm{~g} / \mathrm{kg}, 1.26 \mathrm{~g} / \mathrm{kg}$, $150.7 \mathrm{mg} / \mathrm{kg}, 31.2 \mathrm{mg} / \mathrm{kg}, 136.1 \mathrm{mg} / \mathrm{kg}$, respectively.

The field work was done in 2015 with six treatments (Table 1) and three replicates in a randomized complete block design. Each plot was $58.5 \mathrm{~m}^{2}(6.5 \mathrm{~m} \times 9 \mathrm{~m})$ with $2 \mathrm{~m}$ wide of buffering strip around it. 25\%, 50\%, 75\%, 100\% straw application was set and the rest $\mathrm{N}, \mathrm{P}, \mathrm{K}$ was supplied by mineral fertilizer after nutrients in straw was subtracted in order to maintain the totally same rates of $240 \mathrm{~kg} \mathrm{~N} / \mathrm{hm}^{2}, 154 \mathrm{~kg} \mathrm{P}_{2} \mathrm{O}_{5} / \mathrm{hm}^{2}$ and $197 \mathrm{~kg}$ $\mathrm{K}_{2} \mathrm{O} / \mathrm{hm}^{2}$. Corn straw was taken from other field with Nitrogen $(\mathrm{N})$, phosphorus $(\mathrm{P})$, potassium $(\mathrm{K})$ and moisture contents of $0.72 \%, 0.25 \%, 1.50 \%, 30 \%$, respectively, and crushed into $2-5 \mathrm{~cm}$ length before applying. $100 \%$ straw application amount was determined by grain yield of $12000 \mathrm{~kg} / \mathrm{hm}^{2}$ and the ratio of grain to straw was $1: 1.2$, which was a relatively higher output in local area. The fertilizers were urea ( $\mathrm{N} \mathrm{46 \% ),}$ diammonium $\left(\mathrm{N} 18 \%, \mathrm{P}_{2} \mathrm{O}_{5} 46 \%\right)$ and superphosphate $\left(\mathrm{P}_{2} \mathrm{O}_{5} 46 \%\right)$, potassium chloride $\left(\mathrm{K}_{2} \mathrm{O} 60 \%\right)$, which were products of DQL chemical fertilizer Co., Ltd, China and Yuntianhua Co., Ltd, China. The fertilization detail of each treatment was listed in Table 1.

Table 1. Details of fertilization in each treatment $\left(\mathrm{kg} / \mathrm{hm}^{2}\right)$

\begin{tabular}{c|c|c|c|c|c|c|c|c}
\hline \multirow{2}{*}{ Treatment code } & \multirow{2}{*}{ Treatment } & \multicolumn{3}{|c|}{ Organic material } & \multicolumn{3}{c}{ Mineral fertilizer } \\
\cline { 2 - 8 } & & Rate & $\mathbf{N}$ & $\mathbf{P}_{2} \mathbf{O}_{5}$ & $\mathbf{K}_{2} \mathbf{O}$ & $\mathbf{N}$ & $\mathbf{P}_{2} \mathbf{O}_{5}$ & $\mathbf{K}_{2} \mathbf{O}$ \\
\hline CK & - & 0 & 0 & 0 & 0 & 0 & 0 & 0 \\
IF & 100\% mineral N & 0 & 0 & 0 & 0.0 & 240.0 & 154 & 197 \\
S25 & 25\% maize straw+ mineral N & 3600 & 18.1 & 6.3 & 37.8 & 221.9 & 147.7 & 159.2 \\
S50 & 50\% maize straw+ mineral N & 7200 & 36.2 & 12.6 & 75.6 & 203.8 & 141.4 & 121.4 \\
S75 & 75\% maize straw+ mineral N & 10800 & 54.3 & 18.9 & 113.4 & 185.7 & 135.1 & 83.6 \\
S100 & 100\% maize straw & 14400 & 72.4 & 25.2 & 151.2 & 167.6 & 128.8 & 45.8 \\
\hline
\end{tabular}

Note: CK represented no fertilization treatment, IF represented merely mineral $\mathrm{N}$ fertilization treatment, S25/ S50/ S75/ S100 delegated 25\%/50\%/ 75\%/ 100\% corn straw return + remaining N supplemented by mineral $\mathrm{N}$

Corn (Zea mays L.) hybrid variety XY335 was sowed at one seed per hole with the planting density of $6.5 \times 10^{4}$ plants $/ \mathrm{hm}^{2}$ on 3 May 2015. All mineral $\mathrm{P}$ and K fertilizers, $40 \%$ mineral $\mathrm{N}$ fertilizer and all straw were mixed with top $20 \mathrm{~cm}$ soil before sowing as basal fertilizer. A half of the rested mineral $\mathrm{N}$ fertilizer was applied at the beginning of stem elongation and the other half was applied at inflorescence emergence as top dressing after sample collection. The seeds were sowed after plough, and there was no other tillage during maize growth. It was rain-fed agriculture and no irrigation was given. Weeds were controlled by applying herbicides (atrazine and acetochlor). Corns were harvested on September 29, 2015.

\section{Field investigation and sample collection}

One week after seed germination, number of plants in the whole plot was counted to calculate the germination rate. The plant was sampled in leaf development, early stem elongation, 9 or more nodes detectable, tassel emergency, early grain development, early milk, early ripening and fully ripening stage, which corresponded to 18, 47, 64, 76, 96, 
111, 121 and 131 days after germination, respectively. Soil samples were simultaneously taken in tassel emergency and fully ripening stage.

Representative 3-5 plants were sampled in each plot at each sampling time, washed in deionized water, separated into leaf, stem, ear and grain, oven-dried at $105^{\circ} \mathrm{C}$ for $20 \mathrm{~min}$, followed by drying at $65^{\circ} \mathrm{C}$ until the weight was constant. Then, the plants were crushed and sieved for further analysis. For the last sampling stage, plants in $10 \mathrm{~m}^{2}$ in the middle of each plot were harvested manually to calculate the grain yield on the basis of $14 \%$ moisture content and to determine grain yield components of 1000-grain weight, rows per ear, grain number per row, grain number per ear. No-ear plants were counted in the whole plot.

The soil of 0-100 $\mathrm{cm}$ depth was taken from each plot using a soil probe, and divided into 5 subsamples at each $20 \mathrm{~cm}$ depth. The surface litter was removed before sampling and 3 sites in each plot were randomly taken and then mixed. The soil samples were put into self-sealing plastic bags and brought to lab, stored at $-20^{\circ} \mathrm{C}$ for nitrate and ammonium analysis.

\section{Sample analysis}

The total $\mathrm{N}$ concentration of plants was analyzed by a micro- Kjeldahl procedure after digested by $\mathrm{H}_{2} \mathrm{SO}_{4}-\mathrm{H}_{2} \mathrm{O}_{2}$ (Nelson et al., 1973). The concentration of ammonium and nitrate was measured by continuous flow analyzer (SEAL AutoAnalyzer 3-AA3, Bran and Luebbe, Germany) after being extracted by $2 \mathrm{~mol} / \mathrm{L} \mathrm{KCl} \mathrm{(López} \mathrm{Pasquali} \mathrm{et} \mathrm{al.,} \mathrm{2007).}$

\section{Data processing}

$$
\begin{gathered}
\mathrm{NUE}=\frac{N_{f}-N_{c k}}{F} \times 100 \%(\text { Zhang et al., 2008) } \\
\mathrm{NHI}=\frac{G_{N}}{T P_{\mathrm{N}}}(\text { Afreh et al., 2018) } \\
\mathrm{NAE}=\frac{Y-Y_{0}}{F}(\text { Afreh et al., 2018) }
\end{gathered}
$$

NUE (\%) is nitrogen use efficiency, $\mathrm{N}_{\mathrm{f}}$ is the nitrogen uptake by plant in fertilization treatment, $\mathrm{N}_{\mathrm{ck}}$ is the nitrogen uptake by plant in control, $\mathrm{F}$ is the application amount of mineral $\mathrm{N}$ fertilizer, $\mathrm{NHI}$ is nitrogen harvest index, $\mathrm{G}_{\mathrm{N}}$ is the grains nitrogen uptake, $\mathrm{TP}_{\mathrm{N}}$ is the total nitrogen uptake by plant, NAE $(\mathrm{kg} / \mathrm{kg})$ is nitrogen agronomic efficiency, $\mathrm{Y}$ is the grain yield in fertilization treatment, $\mathrm{Y}_{0}$ is the grain yield in control.

The data were analyzed using SPSS Statistics 17.0 (SPSS, Inc., Chicago, IL, USA), and differences between treatments were compared by the method of least significant difference (LSD) test at the 0.05 level. Microsoft Excel 2016 was adopted for calculating and drawing.

\section{Results}

\section{Grain yield and its components}

Corn grain yield and its components are indicated in Table 2. The results showed that treatments significantly affected germination rate, 1000-grain weight, grains per ear and grain yield $(p<0.05)$. 
Table 2. Germination rate and grain yield components of corn in different fertilization treatments

\begin{tabular}{c|c|c|c|c|c|c}
\hline Treatment & $\begin{array}{c}\text { Germination } \\
\text { rate }(\boldsymbol{\%})\end{array}$ & $\begin{array}{c}\text { No-ear Ratio } \\
(\boldsymbol{\%})\end{array}$ & $\begin{array}{c}\text { 1000-grain weight } \\
(\mathbf{g})\end{array}$ & $\begin{array}{c}\text { Rows per } \\
\text { ear }\end{array}$ & Grains per ear & $\begin{array}{c}\text { Grain yield } \\
\left(\mathbf{k g} / \mathbf{h m}^{\mathbf{2}} \mathbf{\mathbf { D W }}\right)\end{array}$ \\
\hline $\mathrm{CK}$ & $94.9 \pm 1.3 \mathrm{a}$ & $9.8 \pm 1.3 \mathrm{a}$ & $228.3 \pm 23.6 \mathrm{e}$ & $16.1 \pm 0.6 \mathrm{ab}$ & $505.4 \pm 97.8 \mathrm{c}$ & $5654 \pm 666 \mathrm{c}$ \\
$\mathrm{IF}$ & $92.5 \pm 1.0 \mathrm{~b}$ & $5.9 \pm 3.5 \mathrm{~b}$ & $339.7 \pm 12.7 \mathrm{ab}$ & $16.3 \pm 0.3 \mathrm{a}$ & $662.5 \pm 25.8 \mathrm{ab}$ & $8357 \pm 189 \mathrm{a}$ \\
$\mathrm{S} 25$ & $93.2 \pm 1.3 \mathrm{~b}$ & $0.7 \pm 1.3 \mathrm{c}$ & $315.3 \pm 2.7 \mathrm{abc}$ & $16.3 \pm 0.1 \mathrm{a}$ & $574.4 \pm 49.3 \mathrm{bc}$ & $8175 \pm 123 \mathrm{ab}$ \\
$\mathrm{S} 50$ & $93.7 \pm 3.1 \mathrm{~b}$ & $1.5 \pm 1.3 \mathrm{c}$ & $303.1 \pm 37.5 \mathrm{~cd}$ & $16.4 \pm 0.2 \mathrm{a}$ & $644.8 \pm 36.6 \mathrm{ab}$ & $8235 \pm 534 \mathrm{a}$ \\
$\mathrm{S} 75$ & $89.9 \pm 2.5 \mathrm{c}$ & $3.4 \pm 4.2 \mathrm{c}$ & $304.6 \pm 14.3 \mathrm{bc}$ & $16.5 \pm 0.6 \mathrm{a}$ & $673.7 \pm 35.1 \mathrm{a}$ & $8402 \pm 735 \mathrm{a}$ \\
$\mathrm{S} 100$ & $80.0 \pm 0.8 \mathrm{c}$ & $8.0 \pm 0.0 \mathrm{ab}$ & $349.2 \pm 8.7 \mathrm{a}$ & $14.1 \pm 1.5 \mathrm{~b}$ & $565.5 \pm 58.9 \mathrm{ab}$ & $7432 \pm 232 \mathrm{~b}$ \\
\hline
\end{tabular}

Note: Different letters in the same column signified significant difference at $\mathrm{p}<0.05$. CK represented no fertilization treatment, IF represented merely mineral N fertilization treatment, S25/ S50/ S75/ S100 delegated $25 \% / 50 \% / 75 \% / 100 \%$ corn straw return + remaining N supplemented by mineral $\mathrm{N}$

Germination rate in all fertilization treatments was $1.2-14.9 \%$ lower than CK and decreased as straw application was increasing with S75, S100 significantly lower than $\mathrm{S} 25, \mathrm{~S} 50$ by an average of $8.5 \%(p<0.05)$. Appropriate straw application (S25, S50, S75) decreased no-ear ratio by an average of $4.0 \%$ compared to IF and $7.9 \%$ compared to CK. S100 had an opposite effect on it. Meanwhile, S100 decreased rows per ear by 2.2 and grain yield by $925 \mathrm{~kg} / \mathrm{hm}^{2}$ compared to IF. No significant difference was found for the grain per ear values of different treatments $(p>0.05)$. Grain yield of the $100 \%$ mineral treatment was significantly lower than the others $(p<0.05)$.

\section{Nitrogen accumulation in corn plant}

The $\mathrm{N}$ assimilation of whole corn plant in different growth stage was showed in Figure 1. The tassel emergency stage (represented vegetative stage) as well as fully ripening stage (represented reproductive stage) was selected to analyze $\mathrm{N}$ distribution in different plant organ and the results were listed in Figure 2.

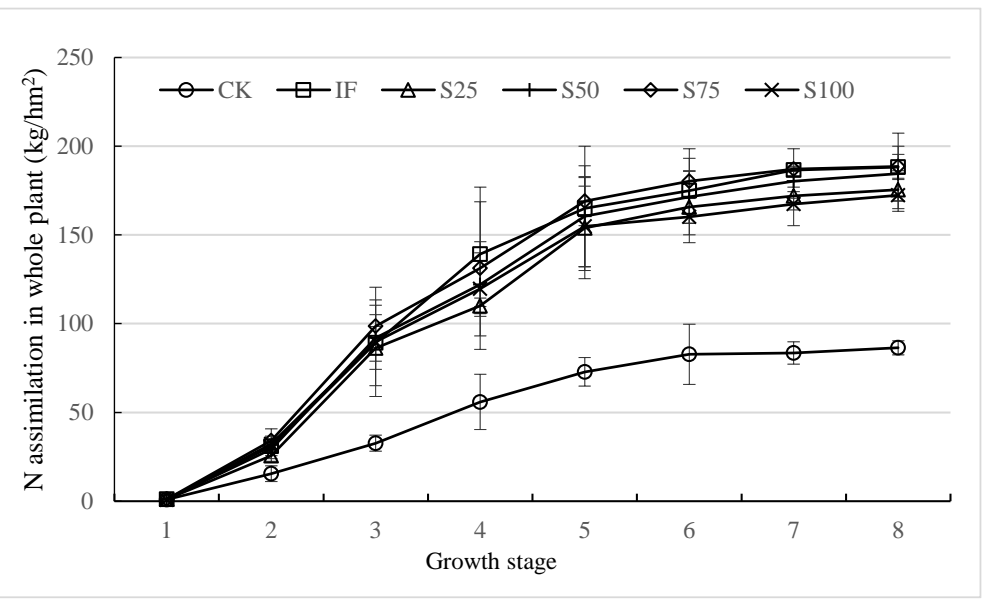

Figure 1. $N$ assimilation amount in whole corn plant during different growth period in different fertilization treatments. Growth stages: 1- leaf development, 2-early stem elongation, 3-9 or more nodes detectable, 4- tassel emergency, 5- early grain development, 6- early milk stage, 7early ripening and 8 - fully ripening. $C K$ represented no fertilization treatment, IF represented merely mineral $N$ fertilization treatment, S25/S50/S75/S100 delegated 25\%/50\%/75\%/100\% corn straw return + remaining $N$ supplemented by mineral $N$ 


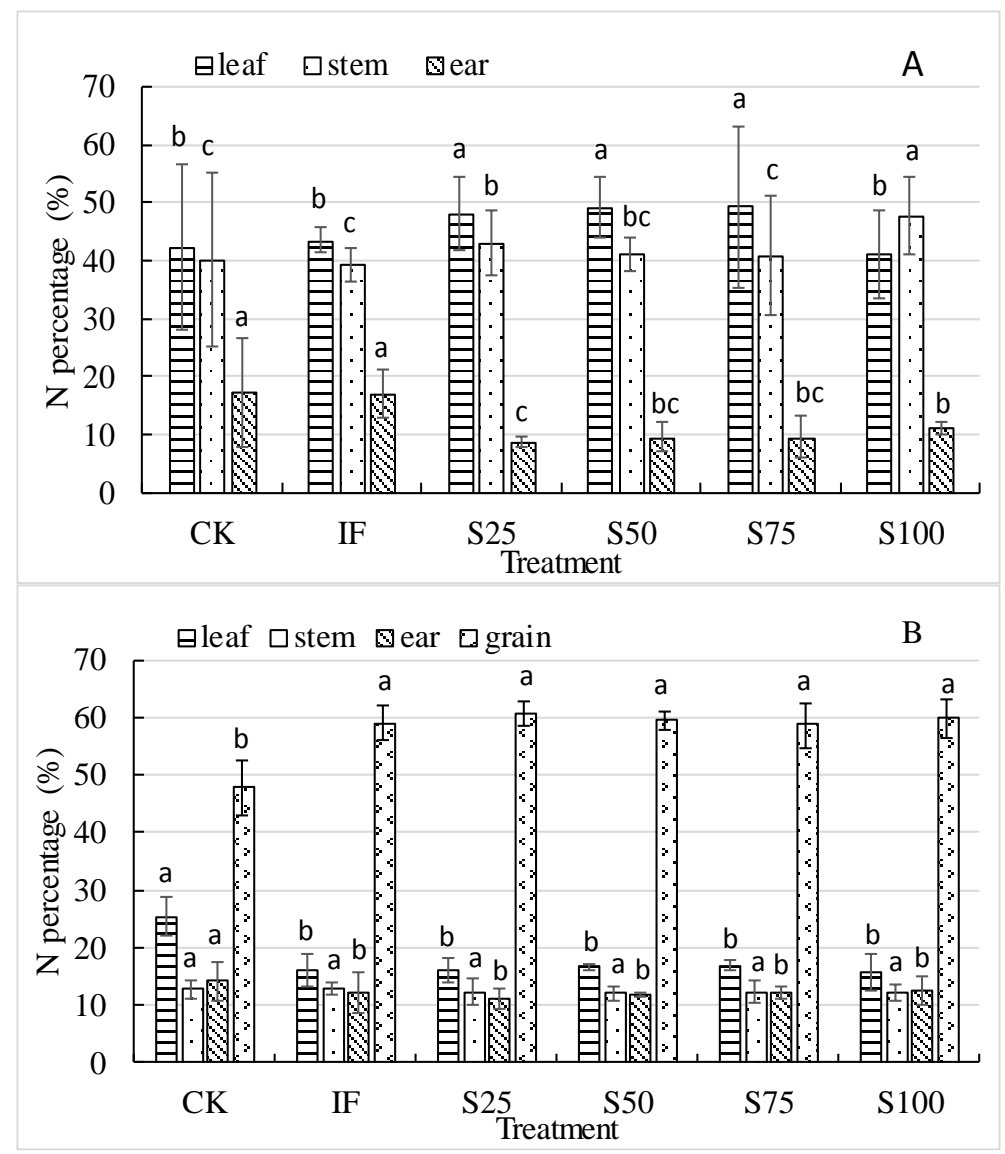

Figure 2. $N$ uptake in different plant organ to the total of plant in tassel emergency (A) and fully ripening stage (B). CK represented no fertilization treatment, IF represented merely mineral $N$ fertilization treatment, S25/S50/S75/S100 delegated 25\%/50\%/75\%/100\% corn straw return + remaining $N$ supplemented by mineral $N$

Compared with CK, fertilization significantly increased $\mathrm{N}$ assimilation amount by $86.0-102.3 \mathrm{~kg} / \mathrm{hm}^{2}$, or $99.7 \%-118.5 \%$ in the fully ripening stage. But there was no obvious difference between straw application treatments and IF except for S100 in leaf development stage and early ripening stage, which was significantly lower than IF $(p<0.05)$.

Straw application promoted $\mathrm{N}$ accumulating in leaves and stems during vegetative growth as N proportion in leaves for S25, S50 and S75 was obviously higher than other organs during tassel emergency stage. And $\mathrm{N}$ proportion in ears increased significantly from $8.8 \%$ in $\mathrm{S} 25$ to $11.1 \%$ in $\mathrm{S} 100$. In fully ripening stage, $\mathrm{N}$ proportion in leaves decreased from an average of $47.0 \%$ in tassel emergency stage to an average of $16.3 \%$, and stems declined from $43.3 \%$ to $12.2 \%$. While for ears, it increased from $9.8 \%$ to $11.9 \%$. For IF, $\mathrm{N}$ in leaves and stems decreased by $27.5 \%$ and $26.6 \%$, respectively, which were lower than those of straw application treatments.

\section{Nitrogen use efficiency}

$\mathrm{N}$ uptake by plant and relevant indicators are list in Table 3. Compared with $\mathrm{CK}, \mathrm{N}$ uptake and $\mathrm{N}$ harvest index was significantly higher for fertilization treatments. While no significant difference was found for $\mathrm{N}$ uptake by plant between IF and the straw 
application treatments $(p>0.05)$. The $\mathrm{N}$ use efficiency of the S75 was $12.6 \%$ significantly higher than IF $(p<0.05)$. No significant difference was observed for nitrogen harvest index and apparent nitrogen recovery $(p>0.05)$ (Table 3), while the $\mathrm{N}$ agronomic efficiency of the S100 was significantly lower than the rest four straw application treatment and IF $(p<0.05)$.

Table 3. Nitrogen use efficiency of corn in different fertilizer treatments

\begin{tabular}{c|c|c|c|c}
\hline Treatment & $\begin{array}{c}\text { N uptake by } \\
\text { plant }\left(\mathbf{k g} / \mathbf{h m}^{\mathbf{2}}\right)\end{array}$ & $\begin{array}{c}\text { N use efficiency } \\
(\boldsymbol{\%})\end{array}$ & N harvest index & $\begin{array}{c}\text { N agronomic efficiency } \\
\mathbf{( k g / k g )}\end{array}$ \\
\hline CK & $86.3 \pm 4.1 \mathrm{~b}$ & - & $0.45 \pm 0.02 \mathrm{~b}$ & - \\
IF & $188.2 \pm 8.4 \mathrm{a}$ & $42.5 \pm 3.5 \mathrm{bc}$ & $0.51 \pm 0.03 \mathrm{a}$ & $11.3 \pm 0.8 \mathrm{a}$ \\
$\mathrm{S} 25$ & $175.5 \pm 5.0 \mathrm{a}$ & $40.2 \pm 2.2 \mathrm{c}$ & $0.53 \pm 0.02 \mathrm{a}$ & $11.4 \pm 0.6 \mathrm{a}$ \\
$\mathrm{S} 50$ & $184.6 \pm 8.6 \mathrm{a}$ & $48.2 \pm 4.2 \mathrm{abc}$ & $0.52 \pm 0.03 \mathrm{a}$ & $12.7 \pm 2.6 \mathrm{a}$ \\
$\mathrm{S} 75$ & $188.6 \pm 11.6 \mathrm{a}$ & $55.1 \pm 6.2 \mathrm{a}$ & $0.51 \pm 0.01 \mathrm{a}$ & $14.8 \pm 4.0 \mathrm{a}$ \\
$\mathrm{S} 100$ & $172.3 \pm 19.5 \mathrm{a}$ & $51.3 \pm 11.6 \mathrm{ab}$ & $0.52 \pm 0.04 \mathrm{a}$ & $10.6 \pm 1.4 \mathrm{~b}$ \\
\hline
\end{tabular}

Note: Different letters in the same column signify significant difference at $p<0.05$. CK represented no fertilization treatment, IF represented merely mineral N fertilization treatment, S25/ S50/ S75/ S100 delegated $25 \% / 50 \% / 75 \% / 100 \%$ corn straw return + remaining $\mathrm{N}$ supplemented by mineral $\mathrm{N}$

\section{Nitrate distribution in soil profile}

Nitrate distribution in soil profile is indicated in Table 4. $\mathrm{NO}_{3}{ }^{-} \mathrm{N}$ in all straw application treatments were lower than IF in both growth stages, and decreased with soil depth and straw application increasing.

Table 4. $\mathrm{NO}_{3}^{-}-\mathrm{N}$ content in soil profile in different fertilization treatments in tasseling and fully ripening stage $(\mathrm{mg} / \mathrm{kg})$

\begin{tabular}{c|c|c|c|c|c|c|c}
\hline & Profile & CK & IF & S25 & S50 & S75 & S100 \\
\hline & $0-20 \mathrm{~cm}$ & $3.4 \pm 0.9 \mathrm{~d}$ & $22.6 \pm 2.9 \mathrm{a}$ & $19.8 \pm 1.0 \mathrm{ab}$ & $17.5 \pm 1.0 \mathrm{bc}$ & $16.4 \pm 1.1 \mathrm{c}$ & $14.5 \pm 2.7 \mathrm{c}$ \\
Tassel & $20-40 \mathrm{~cm}$ & $4.0 \pm 1.6 \mathrm{~d}$ & $22.1 \pm 5.5 \mathrm{a}$ & $19.5 \pm 1.6 \mathrm{~b}$ & $13.1 \pm 2.5 \mathrm{c}$ & $9.2 \pm 0.9 \mathrm{c}$ & $10.3 \pm 3.0 \mathrm{c}$ \\
emergency & $40-60 \mathrm{~cm}$ & $3.3 \pm 1.1 \mathrm{~d}$ & $18.1 \pm 1.9 \mathrm{a}$ & $15.7 \pm 3.0 \mathrm{~b}$ & $10.6 \pm 1.8 \mathrm{c}$ & $8.9 \pm 1.5 \mathrm{c}$ & $5.2 \pm 1.3 \mathrm{~d}$ \\
stage & $60-80 \mathrm{~cm}$ & $3.0 \pm 0.9 \mathrm{c}$ & $12.6 \pm 6.6 \mathrm{ab}$ & $13.8 \pm 1.6 \mathrm{a}$ & $11.4 \pm 1.7 \mathrm{~b}$ & $4.5 \pm 1.0 \mathrm{c}$ & $3.1 \pm 0.8 \mathrm{c}$ \\
& $80-100 \mathrm{~cm}$ & $2.5 \pm 0.2 \mathrm{~d}$ & $13.5 \pm 1.0 \mathrm{a}$ & $11.5 \pm 0.9 \mathrm{~b}$ & $5.6 \pm 1.2 \mathrm{c}$ & $3.2 \pm 0.3 \mathrm{~d}$ & $2.7 \pm 0.5 \mathrm{~d}$ \\
\hline \multirow{3}{*}{ Fully } & $0-20 \mathrm{~cm}$ & $2.9 \pm 0.3 \mathrm{c}$ & $19.3 \pm 1.9 \mathrm{a}$ & $17.3 \pm 5.6 \mathrm{ab}$ & $15.0 \pm 2.1 \mathrm{ab}$ & $14.5 \pm 2.1 \mathrm{ab}$ & $13.0 \pm 1.0 \mathrm{~b}$ \\
ripening & $20-40 \mathrm{~cm}$ & $2.5 \pm 0.7 \mathrm{~d}$ & $18.2 \pm 3.5 \mathrm{~b}$ & $23.3 \pm 2.1 \mathrm{a}$ & $21.7 \pm 4.4 \mathrm{ab}$ & $11.9 \pm 1.7 \mathrm{c}$ & $11.4 \pm 2.4 \mathrm{c}$ \\
stage & $40-60 \mathrm{~cm}$ & $2.0 \pm 0.6 \mathrm{~d}$ & $24.6 \pm 2.7 \mathrm{a}$ & $16.3 \pm 3.2 \mathrm{~b}$ & $14.6 \pm 1.6 \mathrm{~b}$ & $10.0 \pm 0.7 \mathrm{c}$ & $10.5 \pm 1.5 \mathrm{c}$ \\
& $60-80 \mathrm{~cm}$ & $1.2 \pm 0.4 \mathrm{~d}$ & $23.2 \pm 2.8 \mathrm{a}$ & $14.1 \pm 2.2 \mathrm{~b}$ & $15.5 \pm 2.4 \mathrm{~b}$ & $9.1 \pm 0.4 \mathrm{c}$ & $9.2 \pm 1.0 \mathrm{c}$ \\
\hline
\end{tabular}

Note: Different letters in the same column signify significant difference at $\mathrm{p}<0.05$. CK represented no fertilization treatment, IF represented merely mineral N fertilization treatment, S25/ S50/ S75/ S100 delegated $25 \% / 50 \% / 75 \% / 100 \%$ corn straw return + remaining $\mathrm{N}$ supplemented by mineral $\mathrm{N}$

In the tassel emergency stage, $\mathrm{NO}_{3}{ }^{-} \mathrm{N}$ of the $0-20 \mathrm{~cm}$ for all straw application treatments were $12.4 \%, 22.6 \%, 27.4 \%$ and $35.8 \%$ lower than IF, respectively. The differences of the latter three treatments were significant at 0.05 levels, indicating an obvious decreasing trend with increasing straw application rate. Compared to IF, the mean reduction of the four straw application treatments was $5.6 \mathrm{mg} / \mathrm{kg}$ in $0-20 \mathrm{~cm}$, 
$9.0 \mathrm{mg} / \mathrm{kg}$ in $20-40 \mathrm{~cm}, 8.0 \mathrm{mg} / \mathrm{kg}$ in $40-60 \mathrm{~cm}, 4.4 \mathrm{mg} / \mathrm{kg}$ in $60-80 \mathrm{~cm}$ and $7.8 \mathrm{mg} / \mathrm{kg}$ in $80-100 \mathrm{~cm}$. The average $\mathrm{NO}_{3}^{-}-\mathrm{N}$ contents in $0-20 \mathrm{~cm}$ and $80-100 \mathrm{~cm}$ soil layer of all straw application treatments were $17.1 \mathrm{mg} / \mathrm{kg}$ and $5.8 \mathrm{mg} / \mathrm{kg}$, respectively. It decreased by $11.3 \mathrm{mg} / \mathrm{kg}$ from the top layer to the lowest layer, which was larger than that of $9.1 \mathrm{mg} / \mathrm{kg}$ in IF. More straw application was added, lower $\mathrm{NO}_{3}^{-}-\mathrm{N}$ was obtained. For $\mathrm{S} 100$, it decreased by $8.1-12.9 \mathrm{mg} / \mathrm{kg}$ in different soil layers, or $35.8 \%-80.0 \%$ compared with corresponding layers of IF, which decreased more than other straw application treatments.

In the fully ripening stage, $\mathrm{NO}_{3}^{-}-\mathrm{N}$ in all straw application treatments was still lower than IF. For IF, $\mathrm{NO}_{3}{ }^{-} \mathrm{N}$ distribution in soil profile showed a completely opposite characteristic to tassel emergency stage as $40-100 \mathrm{~cm}$ soil layers was $3.9 \mathrm{mg} / \mathrm{kg}$ higher than that in $0-40 \mathrm{~cm}$, which indicated that more $\mathrm{NO}_{3}{ }^{-} \mathrm{N}$ migrated to deeper soil layers. But for all straw application treatments, it was still higher in the two top layers than that in $40-100 \mathrm{~cm}$ with an average content of $14.8 \mathrm{mg} / \mathrm{kg}$ to $12.0 \mathrm{mg} / \mathrm{kg}$, which decreased by $4.0 \mathrm{mg} / \mathrm{kg}$ in $0-40 \mathrm{~cm}$ and $10.7 \mathrm{mg} / \mathrm{kg}$ in $40-100 \mathrm{mg} / \mathrm{kg}$ compared with the corresponding layers of IF. A larger decreasing occurred in deeper layers of straw application treatments indicated that straw combined with reduced mineral $\mathrm{N}$ fertilizer prevented nitrate nitrogen leaching in soil profile. As straw application increasing companied by mineral $\mathrm{N}$ fertilizer application decreasing, less $\mathrm{NO}_{3}{ }^{-}-\mathrm{N}$ was left in soil profile. S100 had the lowest level with a decrease of $6.3-14.1 \mathrm{mg} / \mathrm{kg}$, or $32.6 \%$ - $64.0 \%$ in different soil layers compared with IF.

\section{Ammonium distribution in soil profile}

Ammonium distribution in soil profile is indicated in Table 5. $\mathrm{NH}_{4}{ }^{+}-\mathrm{N}$ in all fertilization treatments was significantly higher than CK $(p<0.05)$ and high level of straw application was significantly higher than IF.

Table 5. $\mathrm{NH}_{4}^{+}-\mathrm{N}$ content in soil profile in different fertilization treatments in tasseling and fully ripening stage $(\mathrm{mg} / \mathrm{kg})$

\begin{tabular}{c|c|c|c|c|c|c|c}
\hline & Profile & CK & IF & S25 & S50 & S75 & S100 \\
\hline & $0-20 \mathrm{~cm}$ & $3.2 \pm 1.0 \mathrm{~b}$ & $11.8 \pm 1.6 \mathrm{a}$ & $11.3 \pm 1.6 \mathrm{a}$ & $12.3 \pm 1.2 \mathrm{a}$ & $12.5 \pm 3.3 \mathrm{a}$ & $10.6 \pm 2.7 \mathrm{a}$ \\
Tassel & $20-40 \mathrm{~cm}$ & $3.8 \pm 0.7 \mathrm{c}$ & $12.0 \pm 1.3 \mathrm{a}$ & $12.8 \pm 1.9 \mathrm{a}$ & $10.5 \pm 2.4 \mathrm{ab}$ & $11.3 \pm 1.8 \mathrm{ab}$ & $8.9 \pm 0.2 \mathrm{~b}$ \\
emergency & $40-60 \mathrm{~cm}$ & $3.6 \pm 0.5 \mathrm{~d}$ & $5.6 \pm 0.6 \mathrm{c}$ & $5.8 \pm 0.3 \mathrm{c}$ & $10 \pm 1.7 \mathrm{ab}$ & $10.6 \pm 1.2 \mathrm{a}$ & $8.8 \pm 0.3 \mathrm{~b}$ \\
stage & $60-80 \mathrm{~cm}$ & $2.5 \pm 0.7 \mathrm{c}$ & $5.8 \pm 0.9 \mathrm{~b}$ & $5.3 \pm 0.6 \mathrm{~b}$ & $9.7 \pm 1.4 \mathrm{a}$ & $10.6 \pm 1.2 \mathrm{a}$ & $6.8 \pm 0.8 \mathrm{~b}$ \\
& $80-100 \mathrm{~cm}$ & $1.1 \pm 0.5 \mathrm{c}$ & $3.2 \pm 0.6 \mathrm{~b}$ & $3.1 \pm 0.5 \mathrm{~b}$ & $4.5 \pm 0.9 \mathrm{ab}$ & $5.3 \pm 1.2 \mathrm{a}$ & $5.2 \pm 0.8 \mathrm{a}$ \\
\hline & $0-20 \mathrm{~cm}$ & $2.3 \pm 0.5 \mathrm{c}$ & $9.2 \pm 1.0 \mathrm{~b}$ & $12.6 \pm 1.1 \mathrm{a}$ & $11.5 \pm 2.6 \mathrm{ab}$ & $12.9 \pm 1.4 \mathrm{a}$ & $13.4 \pm 2.5 \mathrm{a}$ \\
Fully & $20-40 \mathrm{~cm}$ & $2.5 \pm 0.5 \mathrm{c}$ & $8.5 \pm 0.9 \mathrm{~b}$ & $11.7 \pm 0.9 \mathrm{a}$ & $11.3 \pm 0.3 \mathrm{a}$ & $11.8 \pm 0.3 \mathrm{a}$ & $10.8 \pm 0.8 \mathrm{a}$ \\
ripening & $40-60 \mathrm{~cm}$ & $2.3 \pm 0.4 \mathrm{~d}$ & $3.4 \pm 0.3 \mathrm{~d}$ & $6.1 \pm 0.7 \mathrm{c}$ & $8.8 \pm 0.9 \mathrm{ab}$ & $8.6 \pm 0.9 \mathrm{~b}$ & $10.1 \pm 0.9 \mathrm{a}$ \\
stage & $60-80 \mathrm{~cm}$ & $1.5 \pm 0.2 \mathrm{e}$ & $4.0 \pm 0.4 \mathrm{~d}$ & $4.5 \pm 0.5 \mathrm{~d}$ & $10.7 \pm 1.0 \mathrm{~b}$ & $14.0 \pm 0.8 \mathrm{a}$ & $8.7 \pm 0.6 \mathrm{c}$ \\
& $80-100 \mathrm{~cm}$ & $0.9 \pm 0.1 \mathrm{c}$ & $5.7 \pm 0.7 \mathrm{~b}$ & $5.6 \pm 0.2 \mathrm{~b}$ & $5.3 \pm 0.7 \mathrm{~b}$ & $7.4 \pm 0.3 \mathrm{a}$ & $7.3 \pm 0.8 \mathrm{a}$ \\
\hline
\end{tabular}

Note: Different letters signified significant difference at $p<0.05$ among different treatments. CK represented no fertilization treatment, IF represented merely mineral $\mathrm{N}$ fertilization treatment, S25/S50/S75/S100 delegated 25\%/50\%/75\%/100\% corn straw return + remaining N supplemented by mineral $\mathrm{N}$

In the tassel emergency stage, no significant difference was found between $\mathrm{NH}_{4}{ }^{+}-\mathrm{N}$ content of IF and straw application treatments in the $0-20 \mathrm{~cm}$ and $20-40 \mathrm{~cm}$ soil layers $(p>0.05$ ). While it was obviously increased by $3.2 \mathrm{mg} / \mathrm{kg}$ in $40-60 \mathrm{~cm}, 2.3 \mathrm{mg} / \mathrm{kg}$ in 
$60-80 \mathrm{~cm}$ and $1.3 \mathrm{mg} / \mathrm{kg}$ in $80-100 \mathrm{~cm}$. S75 had the highest $\mathrm{NH}_{4}{ }^{+}-\mathrm{N}$ content, which was $5.9 \%-89.3 \%$ more than IF in different soil layers.

In the fully ripening stage, $\mathrm{NH}_{4}{ }^{+}-\mathrm{N}$ in each soil layer increased with straw application increasing and it was significantly higher $(p<0.05)$ than IF and CK by an average of $3.5 \mathrm{mg} / \mathrm{kg}$ and $7.8 \mathrm{mg} / \mathrm{kg}$, respectively. The same as tasseling stage, $\mathrm{NH}_{4}{ }^{+}-\mathrm{N}$ declined with soil depth, while straw application treatments could slow down this trend in $40-80 \mathrm{~cm}$ with an average of $8.9 \mathrm{mg} / \mathrm{kg}$ compared with $3.7 \mathrm{mg} / \mathrm{kg}$ of IF. Compared to tassel emergency stage, $\mathrm{NH}_{4}{ }^{+}-\mathrm{N}$ in CK and IF declined by $0.9 \mathrm{mg} / \mathrm{kg}$ and $1.5 \mathrm{mg} / \mathrm{kg}$, respectively. Whereas straw application treatments enhanced $\mathrm{NH}_{4}{ }^{+}-\mathrm{N}$ content by an average of $0.9 \mathrm{mg} / \mathrm{kg}$, which meant that straw combined with mineral $\mathrm{N}$ fertilizer relatively kept $\mathrm{N}$ in the form of $\mathrm{NH}_{4}{ }^{+}-\mathrm{N}$ long time and it may be related to the inhibition of nitrification.

\section{Discussion}

\section{Effect of straw application combined with reduced mineral $N$ on corn grain yield}

In the present work, the corn yield of straw application treatments was significantly higher $(p<0.05)$ than CK, which was consistent with other results (Uzoma et al., 2011; Liang et al., 2013). However, it did not show significantly higher than merely mineral fertilizer (IF) treatment in our research. There were two kinds of completely different view on the effect of applying organic matter on grain yield. Some results showed organic combined with mineral fertilizer improved crop yield greatly, such as Subehia et al. (2013), who confirmed that $50 \% \mathrm{~N}$ replaced by farmyard manure greatly increased rice and wheat yield than $100 \%$ chemical fertilizer treatment. While a number of previous studies had opposite results, which indicated that nitrogen application amount was the key factor affecting crop yield compared to fertilizer types. For example, Basso et al. (2005) and Biau et al. (2012) thought there was no significant difference in corn yield between treatments of manure, compost and mineral fertilizer in multi-year field experiment. Luo (2015) found that nitrogen improved corn yield by 53.5\%- $130.7 \%$, while organic fertilizer only increased by $8.8 \%-22.1 \%$. Zhou et al. (2013) deemed that low and high organic and mineral nitrogen ratio was adverse to yield and recommended the best ratio of 2:3 for improvement of Soda Alkali soil.

In our result, straw combined with mineral $\mathrm{N}$ fertilizer didn't significantly increase corn yield compared with IF. It partly was relative to the higher background of SOM in testing soil. New added straw in our study mineralized slowly in the fertilizing year and its contribution to increase SOM was relatively small on the high background. Oldfield (2019) found that crop yield increased significantly with the increase of SOM as it was below 2\%. Zhang et al. (2016) carried out one field experiment on a typically low SOM soil, and also believed that the increase of SOC determined the increase of crop yield. Li et al. (2017b) suggested that replacing partial NPK fertilizers by manure could sustain high corn yield when SOC reached $41.96 \mathrm{Mg}$ C/ha in the Northeast China Plain. If SOC was higher than this threshold, the effect would not be realized. Additionally, it would take at least decade to unfold this effect because it was a long time for microorganism to mineralize manure to release nutrients for crops to take up. Biau et al. (2012) found that the mineral $\mathrm{N}$ fertilizer had higher average grain yield and plant $\mathrm{N}$ uptake than pig slurry and attributed the result to agronomic management practices and the climate. Therefore, the effect of straw application on grain yield and plant $\mathrm{N}$ uptake was determined by multiple factors and it was a comprehensive result. In order to evaluate it correctly, the 
response of corn crops to different forms of $\mathrm{N}$ fertilizer should be considered in the same farming practices and climate.

Furthermore, corn yield didn't keep in the increasing trend, but decreased when straw application increased to $100 \%$. We attributed this phenomenon to its lower germination rate and rows per ear. Although some studies showed that organic matter enhanced the soil water content and was benefit of germination and crop growth (Li et al., 2020), the straw application amount and mode was extremely important factors determined its effect on plant growth (Wang et al., 2018b; Zhen et al., 2020). For example, Fan et al. (2005) found that $3.75 \mathrm{t} /$ ha straw combined with mineral $\mathrm{N}$ and $\mathrm{P}$ increased soil water-holding capacity and improved water availability to plants to increase grain yield, in which the application straw amount was much lower than our experiment and did not influence corn germination rate. Liu et al. (2020) discovered that subsoiling with straw application was a promising strategy to improve wheat yield and water use efficiency for retaining soil water availability, in which subsoiling was done by a rotary cultivator in $40-45 \mathrm{~cm}$ soil depth. It was deeper than our study and kept the surface soil unchanged so that it had little effect on the surface evaporation of soil moisture, and however increased the water holding capacity of subsoil. Zhao et al. (2011) also pointed out that high quantities of decomposed cow dung and mineral fertilizers increased field moisture capacity by $11.25 \%$ and increased grain yield by $0.8 \%-9.4 \%$ than the single chemical fertilizers. The difference between our results was the types of organic matter, which affected soil structure and consequent water availability differently. Moreover, there was no artificial irrigation in our testing area which made the soil germinating condition even worse in a windy and less rainfall climate.

\section{Effect of straw application combined with reduced mineral $N$ on $N$ accumulation in corn plant}

In the present work, as long as the total nitrogen application rates was identical, no matter it was in inorganic/organic form, or combining, their nitrogen harvest index changed little, and was significantly higher than no fertilization treatment. However, this result was not consistent with some others which believed that different nitrogen forms and combining ratio influenced harvest index obviously (Tan et al., 2011). We attributed it to the high background level of SOM which decreased the effect of added straw, and it was also partly related to incomplete decomposition of straw in a short time.

In the whole growth period, fertilization treatments (both organic and inorganic) promoted nitrogen accumulation in plant, and they were significantly higher than CK because more $\mathrm{N}$ was supplied, which is in-line with previous reports (Berenguer et al., 2008). Abbasi and Almas (2012) reported that integrated use of organic and inorganic $\mathrm{N}$ sources increased corn growth and $\mathrm{N}$ uptake by plants compared to sole application of organic or chemical N fertilizer. Rees and Castle (2002) deemed that total uptake of $\mathrm{N}$ by plants in poultry manure was higher than those in ammonium sulphate.

In addition, S75 had the highest nitrogen use efficiency in our study which indicated that appropriately combined with straw and mineral $\mathrm{N}$ fertilizer could increase nitrogen use efficiency significantly. Dordas et al. (2008) and Martínez et al. (2017) pointed out that nitrogen use efficiency decreased with increased mineral fertilizer supply. However, our result was consistent with their conclusion except for S100, which was a little lower than other straw application treatments. We attributed it to the lower germination rate which affected grain yield, as well as to the higher straw application amount which consumed more mineral $\mathrm{N}$ for microbial growth so as to decrease the source of $\mathrm{N}$ for corn 
absorbing. Zhi et al. (2020) conducted a ${ }^{15} \mathrm{~N}$ tracer experiments and deemed that nitrogen use efficiency was different regionally which caused more by soil properties than by climatic factors. In his study, nitrogen use efficiency in Northeast China was 47\%, which was much higher than in North Central region of China (28\%). In our study, the average nitrogen use efficiency of straw application treatments was $48.7 \%$ and the mineral $\mathrm{N}$ fertilizer treatment was $42.5 \%$, which was greatly higher than the average of $38 \%$ in Chinese corn system (Zhi et al., 2020).

\section{Effect of straw application combined with reduced mineral $\mathrm{N}$ on $\mathrm{NO}_{3}^{-}-\mathrm{N}$ distribution in soil profile}

In all, S75 and $\mathrm{S} 100$ greatly declined $\mathrm{NO}_{3}{ }^{-} \mathrm{N}$ in $0-100 \mathrm{~cm}$ soil profile compared with IF and $\mathrm{S} 25, \mathrm{~S} 50$. More $\mathrm{NO}_{3}^{-}-\mathrm{N}$ was kept in $0-40 \mathrm{~cm}$ in all straw application treatments, while a migrating to deeper soil was discovered in IF, which indicated that straw application combined with reduced mineral $\mathrm{N}$ fertilizer affected $\mathrm{NO}_{3}{ }^{-} \mathrm{N}$ distribution in soil profile by two ways, one was to decrease its content and the other was to resist its downward migration to deeper soil layers.

Nevertheless, the results of studies about the effects of organic matter application on nitrate leaching found in literature were discording. Martínez et al. (2017) found that N remained in organic form when manure was applied and was less prone to losses than mineral $\mathrm{N}$ fertilizer. Berenguer et al. (2008) reported that pig slurry treatment had relatively lower level of residual $\mathrm{NO}_{3}{ }^{-} \mathrm{N}$ than equivalent dose of mineral fertilizers and suggested that more $\mathrm{N}$ was immobilized as form of $\mathrm{NH}_{4}{ }^{+}-\mathrm{N}$ in the soil. Bai et al. (2015) also supported the view that beneficial reduction of nitrate leaching was elicited by organic fertilizers. However, some research indicated that manure increased the risk of nitrate leaching if it was applied in autumn-winter application or in soils with high soil organic matter (Chambers et al., 2000; Chalmers, 2001; Wang et al., 2002). We attributed these different opinions to drainage amounts, which was supported by Jabloun et al. (2015) who revealed that $\mathrm{N}$ leaching had a positive relationship with precipitation. In the area of abundant rainfall or artificial irrigation, especially in spring and autumn when the absorption capacity of plants to nitrogen was low, high drainage amount took more nitrogen to migrate down. But in the place with less rain, such as our testing position, more nitrogen fixed by microorganism or absorbed by soil aggregates and stayed in the upper soil which decreased the risk of $\mathrm{N}$ leaching with a positive impact on the environment.

\section{Effect of straw application combined with reduced mineral $\mathrm{N}$ on $\mathrm{NH}_{4}^{+}-\mathrm{N}$ distribution in soil profile}

Consistent with most of previous research, the application of $\mathrm{N}$ (both organic and mineral) in this work enhanced the soil ammonium content in 0-40 cm, which was higher than CK (Martínez et al., 2017). In tassel emergency stage, there was no significant difference about $\mathrm{NH}_{4}{ }^{+}-\mathrm{N}$ between IF treatment and other straw application treatments in the two top layers. But when corn was in mature period, all straw application treatments had higher $\mathrm{NH}_{4}{ }^{+}-\mathrm{N}$ than IF treatment, which could be relative to its sustained release during the whole growth period and the high adsorption capacity caused by straw return. Additionally, temperature at this time was enough high to activate mineralization of microorganisms. And in the later stage of growth, the ability of absorbing nitrogen by plants was weaken and biodegradable organic $\mathrm{N}$ was still decomposed by microorganism which resulted in a higher ammonium content than IF during fully ripening stage. $\mathrm{NH}_{4}{ }^{+}-\mathrm{N}$ 
fixed in the interlayers of the clay minerals or absorbed by the surface of soil particles was not uptake by crop, and was not lost through volatilization, but was immobilized in soil and played an important role in the $\mathrm{N}$ budget.

\section{Conclusions}

Straw return, as an important component of conservation tillage, has been widely adopted across the Northeast plain of China. Straw contains many nutrients which can slowly release for plant growth by microbial mineralization. Whether the released nutrients can replace partial chemical-fertilizers on the purpose of reducing fertilizer application in the fertilization year is still unclear in the intensive and continuous corn planting system in Northeast China.

Our results showed that although straw application did not lead to significantly increase in corn yield compared with merely mineral $\mathrm{N}$ fertilizer, $50 \%-75 \%$ straw application combined with reduced mineral $\mathrm{N}$ fertilizer on a total $\mathrm{N}$ application rate of $240 \mathrm{~kg} \mathrm{~N} / \mathrm{hm}^{2}$ was a relatively better fertilizing strategies from the perspective of both nitrogen use efficiency and residual nitrogen in soil in the fertilization year. This fertilization practice not only improved nitrogen use efficiency by 5.7-12.6\% compared with merely mineral $\mathrm{N}$ fertilizer, but also reduced $\mathrm{NO}_{3}{ }^{-}-\mathrm{N}$ amount and its migration to the lower soil layers to avoid contaminating groundwater. Ammonium content in straw return treatments was higher than merely inorganic fertilizer treatment in the fully ripening stage, which should be further researched to evaluate its role to the next planting in the future study.

Acknowledgements. Authors gratefully acknowledge Lichun Wang of the Jilin Agricultural Science Research Institute for field trial setup and maintenance, and Jingmin Yang of Jilin Agricultural University for the support of chemical analysis. This study was partially funded by the national key research and development program of China (2017YFD0201505).

\section{REFERENCES}

[1] Abbasi, M. K., Almas, K. (2012): Microbial biomass carbon and nitrogen transformations in a loam soil amended with organic-inorganic $\mathrm{N}$ sources and their effect on growth and $\mathrm{N}$-uptake in maize. - Ecological Engineering 39: 123-132.

[2] Afreh, D., Zhang, J., Guan, D. H., Liu, K. L., Song, Z. W., Zheng, C. Y., Deng, A. X., Feng, X. M., Zhang, X., Wu, Y., Huang, Q. R., Zhang, W. J. (2018): Long-term fertilization on nitrogen use efficiency and greenhouse gas emissions in a double maize cropping system in subtropical China. - Soil \& Tillage Research 180: 259-267.

[3] Bai, J. S., Cao, W. D., Xiong, J., Zeng, N. H., Gao, S. J., Shimizu, K. (2015): Integrated application of February Orchid (Orychophragmus violaceus) as green manure with chemical fertilizer for improving grain yield and reducing nitrogen losses in spring maize system in northern China. - Journal of Integrative Agriculture 14: 2490-2499.

[4] Basso, B., Ritchie, J. T. (2005): Impact of compost, manure and inorganic fertilizer on nitrate leaching and yield for a 6-year maize-alfalfa rotation in Michigan. - Agriculture, Ecosystems and Environment 108: 329-341.

[5] Battye, W., Aneja, V. P., Schlesinger, W. H. (2017): Is nitrogen the next carbon? - Earths Future 5: 894-904.

[6] Berenguer, P., Santiveri, F., Boixadera, J., Lloveras, J. (2008): Fertilization of irrigated maize with pig slurry combined with inorganic nitrogen. - Eur. J. Agron. 28: 635-645. 
[7] Biau, A., Santiveri, F., Mijangos, I., Lloveras, J. (2012): The impact of organic and inorganic fertilizers on soil quality parameters and the productivity of irrigated maize crops in semiarid regions. - European Journal of Soil Biology 53: 556-61.

[8] Cai, Z. J., Wang, B. R., Xu, M. G., Zhang, H. M., He, X. H., Zhang, L., Gao, S. D. (2015): Intensified soil acidification from chemical $\mathrm{N}$ fertilization and prevention by manure in an 18-year field experiment in the red soil of southern china. - J. Soils Sediments 15: 260270.

[9] Chalmers, A. G. (2001): A review of fertilizer, lime and organic manure use on farm crops in Great Britain from 1983 to 1987. - Soil Use Manage 17: 254-262.

[10] Chambers, B. J., Smith, K. A., Pain, B. F. (2000): Strategies to encourage better use of nitrogen in animal manures. - Soil Use Manage 16: 157-161.

[11] Cui, Z. L., Zhang, F. S., Chen, X. P., Miao, Y. X., Li, J. L., Shi, L. W., Xu, J. F., Ye, Y. L., Liu, C. S., Yang, Z. P., Zhang, Q., Huang, S. M., Bao, D. (2008): On-farm evaluation of an in-season nitrogen management strategy based on soil $\mathrm{N}_{\min }$ test. - Field Crops Research 105: 48-55.

[12] De Paz, J. M., Ramos, C. (2004): Simulation of nitrate leaching for different nitrogen fertilization rates in a region of Valencia (Spain) using a GIS-GLEAMS system. - Agric., Ecosyst \& Environ. 103: 59-73.

[13] Demelash, N., Bayu, W., Tesfaye, S., Ziadat, F., Sommer, R. (2014): Current and residual effects of compost and inorganic fertilizer on wheat and soil chemical properties. - Nutr. Cycl. Agroecosyst 100: 357-367.

[14] Dordas, C. A., Lithourgidis, A. S., Matsi, T., Barbayiannis, N. (2008): Application of liquid cattle manure and inorganic fertilizers affect dry matter nitrogen accumulation, and partitioning in maize. - Nutr. Cycl. Agroecosyst 80: 283-296.

[15] Fan, T., Stewart, B. A., Yong, W., Luo, J. J., Zhou, G. Y. (2005): Long-term fertilization effects on grain yield, water-use efficiency and soil fertility in the dryland of Loess Plateau in China. - Agriculture, Ecosystems \& Environment 106: 313-329.

[16] Galloway, J. N., Aber, J. D., Erisman, J. W., Seitzinger, S. P., Howarth, R. W., Cowliing, E. B., Cosby, B. J. (2003): The nitrogen cascade. - Bioscience 53: 341-356.

[17] Gao, Q., Feng, G. Z., Wang, Z. G. (2010): Present situation of fertilizer application on spring maize in Northeast China. - Chinese Agricultural Science Bulletin 26: 229-231. (in Chinese).

[18] Guo, J. H., Liu, X. J., Zhang, Y., Shen, J. L., Han, W. X., Zhang, W. F., Christie, P., Goulding, K. W. T., Vitousek, P. M., Zhang, F. S. (2010): Significant acidification in major Chinese croplands. - Science 327: 1008-1010.

[19] Hillin, C. K., Hudak, P. F. (2003): Nitrate contamination in the Seymour aquifer, north central Texas, USA. - Bull. Environ. Contam. Toxicol. 70: 674-679.

[20] Jabloun, M., Schelde, K., Tao, F. L., Olesen, J. E. (2015): Effect of temperature and precipitation on nitrate leaching from organic cereal cropping systems in Denmark. European Journal of Agronomy 62: 55-64.

[21] Li, X. H., Guo, H. H., Zhu, Z. L., Dong, H. Y., Yang, L. P., Zhang, X. J. (2016): Effects of different straw return modes on contents of soil organic carbon and fractions of soil active carbon. - Trans. Chin. Soc. Agric. Eng. 32: 130-135.

[22] Li, H. L., Wang, C., Sun, H. T., Yan, X. L., Liang, Q. (2017a): Comprehensive utilization and sustainable development of agriculture straw. - Journal of Agricultural Mechanization Research 39: 256-262. (in Chinese).

[23] Li, H., Feng, W. T., He, X. H., Zhu, P., Gao, H. J., Sun, N., Xu, M. G. (2017b): Chemical fertilizers could be completely replaced by manure to maintain high maize yield and soil organic carbon (SOC) when SOC reaches a threshold in the Northeast China Plain. Journal of Integrative Agriculture 16: 937-946.

[24] Li, Y. Z., Song, D. P., Dang, P. F., Wei, L. N., Qin, X. L., Siddique, K. H. M. (2020): Combined ditch buried straw return technology in a ridge-furrow plastic film mulch system: Implications for crop yield and soil organic matter dynamics. - Soil \& Tillage Research 
199: 1-9.

[25] Liang, B., Zhao, W., Yang, X. Y., Zhou, J. B. (2013): Fate of nitrogen-15 as influenced by soil and nutrient management history in a 19-year wheat-maize experiment. - Field Crops Res. 144: 126-134.

[26] Liu, C., Lu, M., Cui, J., Li, B., Fang, C. M. (2014): Effects of straw carbon input on carbon dynamics in agricultural soils: a meta-analysis. - Glob. Change Biol. 20: 1366-1381.

[27] Liu, Z., Ma, F. Y., Hu, T. X., Zhao, K. G., Gao, T. P., Zhao, H. X., Ning, T. Y. (2020): Using stable isotopes to quantify water uptake from different soil layers and water use efficiency of wheat under long-term tillage and straw return practices. - Agricultural Water Management 229: 1-9.

[28] López Pasquali, C. E., Fernández Hernando, P., Durand Alegría, J. S. (2007): Spectrophotometric simultaneous determination of nitrite, nitrate and ammonium in soils by flow injection analysis. - Analytica Chimica Acta 600(1-2): 177-182.

[29] Lu, F., Wang, X. K., Han, B., Ouyang, Z. Y., Duan, X. N., Zheng, H., Miao, H. (2009): Soil carbon sequestrations by nitrogen fertilizer application, straw return and no-tillage in China's cropland. - Global Change Biol. 15: 281-305.

[30] Luo, L., Wang, C. B., Pang, H. C., Yang, S. C., Li, Y. Y., Jiang, W. L. (2015): Effects of combined application of organic and inorganic fertilizers on physical and chemical properties and crop yields in alkali-saline soil. - Agricultural Research in the Arid Areas 33(4): 105-111. (in Chinese).

[31] Martínez, E., Domingo, F., Roselló, A., Serra, J., Boixadera, J., Lloveras, J. (2017): The effects of dairy cattle manure and mineral $\mathrm{N}$ fertilizer on irrigated maize and soil $\mathrm{N}$ and organic C. - European Journal of Agronomy 83: 78-85.

[32] Nelson, D. W., Sommers, L. E. (1973): Determination of total nitrogen in plant material. Agronomy Journal 65: 109-112.

[33] Oldfield, E. E., Bradford, M. A., Wood, S. A. (2019): Global meta-analysis of the relationship between soil organic matter and crop yields. - Soil 5: 15-32.

[34] Rasool, R., Kukal, S. S., Hira, G. S. (2008): Soil organic carbon and physical properties as affected by long-term application of FYM and inorganic fertilizers in maize-wheat system. - Soil Till. Res. 101: 31-36.

[35] Rees, B., Castle, K. (2002): Nitrogen recovery in soils amended with organic manures combined with inorganic fertilizers. - Agronomie 22: 739-746.

[36] Subehia, S., Sepehya, S., Rana, S. S., Negi, S. C., Sharma, S. K. (2013): Long-term effect of organic and inorganic fertilizers on rice (Oryza sativa L.)-wheat (Triticum aestivum L.) yield, and chemical properties of an acidic soil in the western Himalayas. - Exp. Agric. 49: 382-394.

[37] Tan, D. S., Liu, Z. H., Jiang, L. H., Zhang, Q., Zheng, F. L., Lin, H. T., Gao, X. H., Xu, Y. (2011): Effect of different fertilization patterns on maize yield, economic benefit and $\mathrm{NO}_{3}{ }^{-}$ -N of soil in Nansi lake basin. - Chinese Journal of Soil Science 42: 887-890. (in Chinese).

[38] Uzoma, K. C., Inoue, M., Andry, H., Fujimaki, H., Zahoor, A., Nishihara, E. (2011): Effect of cow manure biochar on maize productivity under sandy soil condition. - Soil Use Manag 27: 205-212.

[39] Wang, Y., Yamamoto, K., Yakushido, K. (2002): Changes in nitrate N content in different soil layers after the application of livestock waste compost pellets in a sweet corn field. Soil Sci. Plant Nutr. 48: 165-170.

[40] Wang, S. C., Zhao, Y. W., Wang, J. Z., Zhu, P., Cui, X., Han, X. Z., Xu, M. G., Lu, C. A. (2018a): The efficiency of long-term straw return to sequester organic carbon in Northeast China's cropland. - Journal of Integrative Agriculture 17: 436-448.

[41] Wang, X. J., Jia, Z. K., Liang, L. Y., Zhao, Y. F., Yang, B. P., Ding, R. X., Wang, J. P., Nie, J. F. (2018b): Changes in soil characteristics and maize yield under straw return system in dryland farming. - Field Crops Research 218: 11-17.

[42] Xu, J., Han, H. F., Ning, T. Y., Li, Z. J., Lal, R. (2019): Long-term effects of tillage and straw management on soil organic carbon, crop yield, and yield stability in a wheat-maize 
system. - Field Crops Research 233: 33-40.

[43] Zhang, F. S., Wang, J. Q., Zhang, W. F., Cui, Z. L., Ma, W. Q., Chen, X. P., Jiang, R. F. (2008): Nutrient use efficiencies of major cereal crops in China and measures for improvement. - Acta Pedologica Sinica 45: 915-924. (in Chinese).

[44] Zhang, F. S., Cui, Z. L., Fan, M. S., Zhang, W. F., Chen, X. P., Jiang, R. F. (2011): Integrated soil-crop system management: reducing environmental risk while increasing crop productivity and improving nutrient use efficiency in China. - J. Environ. Qual. 40: 10511057.

[45] Zhang, X., Davidson, E. A., Mauzerall, D. L., Searchinger, T. D., Dumas, P., Shen, Y. (2015): Managing nitrogen for sustainable development. - Nature 528: 51-59.

[46] Zhang, Y. L., Li, C. H., Wang, Y. W., Hu, Y. M., Christie, P., Zhang, J. L., Li, X. L. (2016): Maize yield and soil fertility with combined use of compost and inorganic fertilizers on a calcareous soil on the North China Plain. - Soil \& Tillage Research 155: 85-94.

[47] Zhao, J. W., Zhou, L. R. (2011): Combined application of organic and inorganic fertilizers on black soil fertility and maize yield. - Journal of Northeast Agricultural University (English Edition) 18(2): 24-29.

[48] Zhen, W., Song, X. D., Wang, C. R., Hu, Y. J., Si, Z. S. (2020): The effect of the change of corn straw treatment mode on the occurrence of corn disease, insect pests and weeds in Heilongjiang Province. - Heilongjiang Science 11: 43-47.

[49] Zhi, Q., Li, S. L., Zhang, X., Zhu, F. F., Li, P. P., Sheng, R., Chen, X., Zhang, L. M., He, J. Z., Wei, W. X., Fang, Y. T. (2020): Fertilizer nitrogen use efficiency and fates in maize cropping systems across China: Field 15N tracer studies. - Soil \& Tillage Research 197: 19.

[50] Zhou, L. R., Yang, D. C. (2013): Screening of salinization of farmland organic manure and inorganic fertilizer ratio. - Journal of Northeast Agricultural University 44(11): 25-28. (in Chinese).

[51] Zhu, Z. L., Chen, D. L. (2002): Nitrogen fertilizer use in China- contributions to food production impacts on the environment and best management strategies. - Nutrient Cycling in Agroecosystems 63: 117-127. 